\title{
Survey on medicinal plants and spices used in Beni-Sueif, Upper Egypt
}

\author{
Sameh F AbouZid ${ }^{1 *}$ and Abdelhalim A Mohamed $^{2}$
}

\begin{abstract}
Background: This study was conducted to identify medicinal plants and spices used for medicine by the community of Beni-Sueif, Upper Egypt.

Methods: Ethnobotanical data from local people was collected using direct interviews and a semi-structured questionnaire.

Results: Forty-eight plant species belonging to twenty-seven families and forty-seven genera were encountered during the study. Their botanical and vernacular names, plant parts used and medicinal uses are given. Results of the study were analyzed using two quantitative tools. The factor informant consensus indicated the agreement in the use of plants and the fidelity level indicated the ratio between the number of informants who independently suggested the use of a species for the same major purpose and the total number of informants who mentioned the plant for any use. The results of the factor informant consensus showed that the cardiovascular category has the greatest agreement, followed by the immunological, gastrointestinal and respiratory categories. The most important species according to their fidelity are: Hibiscus sabdariffa L. for the cardiovascular category; Trigonella foenum-graecum L. for the immunological category; Mentha piperita L. for the gastrointestinal category and Pimpinella anisum $\mathrm{L}$. for the respiratory category.
\end{abstract}

Conclusions: Medicinal plants are still used for treatment in Beni-Sueif community despite the availability of prescribed medications. Documentation of this ethnomedicinal knowledge is important. Evaluation of pharmacological activity for the promising medicinal plants is suggested.

\section{Background}

The use of medicinal plants has occurred in Egypt since Pharaonic times $[1,2]$. This constituted an integral part of the practiced medicine at that time. Nowadays, Egyptians still depend of medicinal plants for treatment. In a recent study conducted by the Information and Decision Support Centre in Egypt [3], it was found that $23 \%$ of the Egyptian use medicinal plants as a remedy; $52 \%$ of them are living in urban areas and $48 \%$ are living in countryside. It is important to document these uses and perform studies about their pharmacological activities to assure their efficacy and safety.

Beni-Sueif is situated in the north of Upper Egypt and occupies a land area of approximately $10954 \mathrm{~km}^{2}$. The governorate has a total inhabitancy of $1369.41 \mathrm{~km}^{2}$. It

\footnotetext{
* Correspondence: safekry@bsu.edu.eg

'Department of Pharmacognosy, Faculty of Pharmacy, Beni-Sueif University, P.O. Box 62111, Beni-Sueif, Egypt

Full list of author information is available at the end of the article
}

boasts a population of over 2315512. The language of inhabitants is Arabic. Biomedical facilities and prescription medication are available in the towns of the governorate in addition to the herbalist shops. The latter represents the main healthcare facility in the countryside. Beni-Sueif has different phytogeographical regions; the desert regions of the western and eastern sides of the Nile and the Nile-valley characterized by its fertile soil [4]. Beni-Sueif governorate is producing $25 \%$ of medicinal and aromatic plants produced in Egypt. This is mainly because of the presence of suitable climate, fertile soil and availability of irrigation water from the Nile. Pelargonium roseum L., Ocimum basilicum L., Artemisia herba-alba Asso., Mentha piperita L., Coriandrum sativum L., Anethum graveolens L., Origanum majorana L. and Jasminum officinale L. are the most important medicinal and aromatic plants produced in the governorate. Table 1 shows the production figures for these plants.

\section{() Biomed Central}


Table 1 Medicinal and aromatic plant production in BeniSueif, Egypt

\begin{tabular}{lcc}
\hline Plant & $\begin{array}{c}\text { Area (in } \\
\text { Fadden) }\end{array}$ & $\begin{array}{c}\text { Production (ton/ } \\
\text { year) }\end{array}$ \\
\hline Pelargonium roseum L. & 3071 & 56137 \\
Ocimum basilicum L. & 1724 & 2586 \\
Artemisia herba-alba & 1334 & 1100 \\
Asso. & & \\
Anethum graveolens L. & 262 & 2162 \\
Mentha piperita L. & 212 & 262 \\
Coriandrum sativum L. & 127 & 117 \\
Jasminum officinale L. & 53 & 159 \\
Origanum majorana L. & 31 & 26
\end{tabular}

Data source: Investors Service Center, Beni-Sueif governorate http://www. benisuef.gov.eg, 2004.

The present study aims to review traditional ethnomedicinal knowledge of the local people in Beni-Sueif governorate, focusing specifically on the medicinal uses of plants. These types of studies are urgent considering the loss of traditional knowledge accompanying alteration of the physical and biological environment.

\section{Methods}

\section{Data collection}

Direct interviews with the people living in Beni-Sueif governorate (Figure 1) were conducted during the period March-August 2009, using a semi-structured questionnaire [5]. The participants in the interview were chosen from those who declared to know and/or use medicinal plants by a random sampling technique. Recruiters visited participants in their homes and asked them the questions in the questionnaire. Examples of some commonly used medicinal plants were given to make the idea of the study easier for the participants.

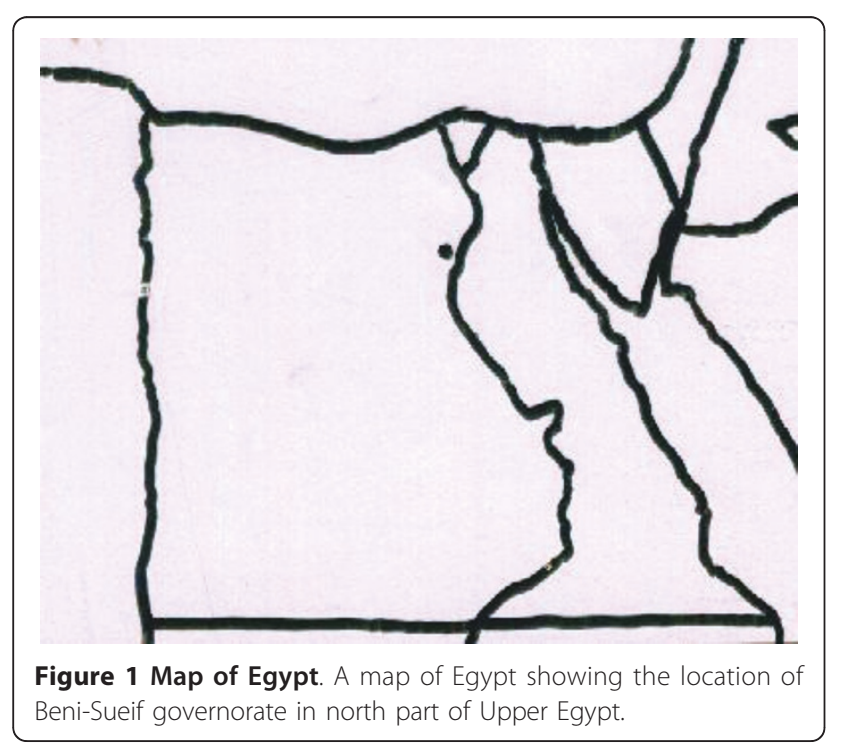

The participants were asked whether they prefer treatment with medicinal plants to conventional drug therapy. The interview was done in Arabic, the language spoken by the people living in the governorate. The information was collected from 57 persons (44 men and 13 women) whose age ranged from $30-70$ years. This includes questions about the plants they use against diseases, parts of the plants used, methods of preparation and sources they obtain these plants. People interviewed are representing urban and rural life styles. The plant materials were obtained from their sources, botanically identified $[4,6]$ and voucher specimens were stored in CAIM herbarium, Flora \& Phyto-taxonomy Researches Department, Horticultural Research Institute, Agricultural Research Centre, Ministry of Agriculture, Egypt.

\section{Quantitative ethnobotany}

The factor informant consensus $\left(\mathrm{F}_{\mathrm{IC}}\right)$ [7] was used for the analysis of the general use of plants. The illnesses were classified into broad disease categories (several diseases based on the organ system in one category) using the following categories: (1) urological (inflammation, calculi, infection), (2) gastrointestinal (mal digestion, ulcer, flatulence, constipation, colic), (3) respiratory (cough, congestion), (4) neurological (anxiety), (5) cardiological (hypertension), (6) dermatological (infection, wounds), (7) immunological (susceptibility to infections), (8) cultural (spices, condiments, heath drink), (9) diabetes, (10) women's health (menstrual pain, hair growth). The $\mathrm{F}_{\mathrm{IC}}$ was calculated as the number of use citations in each category (nur) minus the number of species used (nt), divided by the number of use citations in each category minus one [7]:

$$
\mathrm{F}_{\mathrm{IC}}=\text { nur }-\mathrm{nt} / \mathrm{nur}-1
$$

The fidelity level (FI), which is the ratio between the number of informants who independently suggested the use of a species for the same major purpose and the total number of informants who mentioned the plant for any use, was calculated for the most frequently reported diseases or ailments for the categories with the highest $\mathrm{F}_{\mathrm{IC}}$

$$
\mathrm{FI}(\%)=\mathrm{Np} / \mathrm{N} \times 100
$$

Where $\mathrm{Np}$ is the number of informants that claimed a use of a plant species to treat a particular disease, and $\mathrm{N}$ is the number of informants that used the plant as a medicine to treat any given disease [8].

Number of uses mentioned (Um) refers to the mentions for one plant given by all of the informants for a specific disease.

These tools helped us to determine which illness categories had higher representation (using the $\mathrm{F}_{\mathrm{IC}}$ ) and the plants with major fidelity (using the FI). 


\section{Results}

\section{General analysis of the data}

The results of the study are presented in Table 2, in which the plants are arranged in alphabetical synopsis. For each species, the following information is provided: botanical name, plant family, local name, part used, method of preparation or administration and ailments treated. Forty-eight plant species distributed over twentyseven families and forty-seven genera were discovered to be used by local people of Beni-Sueif. Apiaceae, Fabaceae and Lamiaceae were the most dominant families.

The informants in this study use plants for three main reasons: (1) medicinal plants are safer than prescribed medications (81\%), (2) medicinal plants are cheaper than prescribed medications (11\%) and (3) medicinal plants are easier to get from herbalist shops widely available in rural areas $(8 \%)$. Only $3 \%$ of the informants were against the use of medicinal plants as remedy because of their unknown composition, prescribed medications are more effective and faster in their actions or medicinal plants are not prescribed by the physicians. The plants with the highest number of uses mentioned for any disease were Hibiscus sabdariffa L. (37), Pimpinella anisum L. (34), Mentha piperita L. (32) and Trigonella foenum-graecum L. (25). The complete data are presented in Table 2.

\section{Factor informant consensus and fidelity level}

The results of the $F_{I C}$ showed that the cardiovascular category had the greatest agreement with an $\mathrm{F}_{\mathrm{IC}}$ of 0.88 , followed by immunological disorders $(0.80)$, gastrointestinal disorders (0.78), respiratory disorders $(0.78)$ and neurological disorders (0.50). Within the cardiovascular category, the main reported ailment was hypertension (36 reports). Within the gastrointestinal category, there were 28 reports of colic. Within the respiratory category, there were 19 reports of cough.

We analyzed the categories with the major agreements to indicate the most important plants in each category. For the cardiovascular category, we found that the most important species, according to fidelity, was Hibiscus sabdariffa $(\mathrm{FI}=97.3)$. Trigonella foenum-graecum $(\mathrm{FI}=$ 36) was the most important species for the immunological category. The most important plants in the gastrointestinal category were Mentha piperita $(\mathrm{FI}=87.5)$, Trigonella foenum-graecum (FI = 56) and Pimpinella anisum (FI = 32.4). Pimpinella anisum (FI = 55.9) was the most important plant in the respiratory category.

\section{Correlation between number of uses mentioned and fidelity level}

The categories of the plants with higher number of uses mentioned (for one purpose) were correlated with their fidelity level (Table 2). The plants with higher number of uses mentioned for all categories were Hibiscus sabdariffa with 36 mentions for hypertension (FI = 97.3), Mentha piperita with 28 mentions for colic in gastrointestinal tract (FI = 87.5), Trigonella foenumgraecum with 14 mentions for colic in gastrointestinal tract $(\mathrm{FI}=56)$ and Pimpinella anisum with 19 mentions for upper respiratory tract problems $(F I=55.9)$. Some plants showed a high fidelity level $(\mathrm{FI}=100)$ for one ailment such as Ambrosia maritima L. for renal colic (4), Boswellia carterii Birdw. as expectorant (4), Cassia acutifolia Delile. for constipation (6) and Tilia sylvestris Desf. for cough (4). The following plants were mentioned once that is considered of low fidelity: Ammi visnaga (L.) Lam. as diuretic, Capsicum annum L. as a condiment, Cladium mariscus (L.) Pohl for colic in gastrointestinal tract, Coffea arabica L. for healing of wounds, Commiphora myrrha Engl. for cough, Cyperus longus L. for decreasing hair growth, Myristica fragrans Houtt as a condiment, Orchis hircine Crantz. for peptic ulcer, Piper nigrum L. as a condiment and Plantago afra L. as antiseptic for skin.

\section{Discussion}

Documentation of ethnobotanical knowledge is important to study/understand human-plant relationships [9], implement general policies about the use of natural resources [10] and assess potential livelihood and monetary benefits $[11,12]$.

In this work, we used two quantitative tools to study the main medicinal plants and spices used by the local people in Beni-Sueif governorate. With the $\mathrm{F}_{\mathrm{IC}}$, the main categories of health conditions for which plants are used, are detected, and with the FI, we selected the most important species from these categories. The cardiovascular, immunological, gastrointestinal and respiratory categories used the most plants.

The FI and the number of uses mentioned support the $\mathrm{F}_{\mathrm{IC}}$. This is indicated by the observation that the cardiovascular category has the highest $F_{I C}$. This means that the cardiovascular illnesses have the greatest agreement among the informants for being treated by medicinal plants. Hibiscus sabdariffa, the most used plant in the cardiovascular category, has the highest FI and number of uses mentioned among all of the plants. Therefore, the $\mathrm{F}_{\mathrm{IC}}$ is a good analytical tool to select categories of illness when analyzing the data as they are presented here.

If we consider FI and the use mentions to analyze the most important plants, we get the following plants: Hibiscus sabdariffa for hypertension, Mentha piperita for colic in gastrointestinal tract, Trigonella foenumgraecum for colic in gastrointestinal tract and Pimpinella anisum for upper respiratory tract problems. 
Table 2 Medicinal plant species, plant parts used and ailments treated by local people of Beni-Sueif, Egypt

Plant name Voucher specimen code Used part
CAIM101, B

Allium sativum L. (Alliaceae), Thawm, cultivated, CAIM102, B

Ambrosia maritima L., (Asteraceae), Damsis, wild, CAIM110, L

Ammi visnaga (L.) Lam. (Apiaceae), Khillah, cultivated, Decoction CAIM103, S

Amomum cardamom L. (Zingiberaceae), Habbahan, imported, CAIM144, Fr

Artemisia herba-alba Asso. (Asteraceae), Shihh, wild, CAIM111, L, F

Boswellia carterii Birdw. (Burseraceae), Lubn dhakar, imported, CAIM113, G

Camellia sinensis L. Kuntze, (Theaceae), Shay akhdar, Infusion imported, CAIM142, L

Capsicum annum L. (Solanaceae), Fulful ahhmar, Powder imported, CAIM140, Fr

Carum carvi L. (Apiaceae), Karawya, cultivated, CAIM104, Fr

Caryophyllus aromaticus L. (Myrtaceae), Qurunfil, cultivated, CAIM130, Fb

Cassia acutifolia Delile. (Fabaceae), Sana makki, imported, CAIM118, L

Ceratonia siliqua L. (Fabaceae), Carob, cultivated, CAIM119, Fr, I

Cinnamomum verum J. Presl (Lauraceae), Qirfah, imported, CAIM124, Bk

Citrus limon (L.) Burm. F. (Rutaceae), Laymun, cultivated, CAIM137, Fr

Cladium mariscus (L.) Pohl (Cyperaceae), Hhalfa, wild, Decoction CAIM115, L

Coffea arabica L. (Rubiaceae), Bunn, imported, Powder CAIM138, Be

Commiphora myrrha Engl. (Burseraceae), Murr, imported, CAIM114, G

Coriandrum sativum L. (Apiaceae), Kuzbarah, Powder, green herb cultivated, CAIM105, Fr, L

Cuminum cyminum L. (Apiaceae), Kammun, cultivated, Powder, decoction CAIM106, Fr

Cyperus longus L. (Cyperaceae), Su'd, wild CAIM116, L Powder

Foeniculum vulgare Mill. (Apiaceae), Shamar, Decoction cultivated, CAIM107, Fr

Glossostemon bruguieri Desf., (Sterculiaceae), Moghat, imported, CAIM141, Rt

Glyccyrrhiza glabra L. (Fabaceae), Erq sus, imported, CAIM120, Rt

Hordeum vulgare L. (Gramineae), Sha'ir, cultivated, CAIM123, Be

Hibiscus sabdariffa L. (Malvaceae), Karkareeh, cultivated, CAIM131, F

Hyphaene thebaica (L.) C. Martius, (Palmae), Doum, wild, CAIM134, Fr

Lupinus albus L. (Fabaceae), Turmes murr, cultivated, CAIM121, S

Matricaria recutita (L.) Rauschert, (Asteraceae), Babunag, cultivated, CAIM112, F nuts and coconut. diluted with water.

Decoction

Powder

Decoction, powder
Use/ailment treated (No. of uses mentioned, Fl)

Heart diseases $(1,50)$, antiseptic for mouth infections $(1,50)$

Memory loss $(1,20)$, hypertension $(2,40)$, microbial infections $(2,40)$

Renal colic $(4,100)$

Diuretic $(1,100)$

For general well-being $(3,100)$

Colic in GIT $(2,100)$

Expectorant $(4,100)$

For diet purpose $(3,100)$

Condiment $(1,100)$

Colic in GIT $(3,75)$, hypertension $(1,25)$

Toothache $(2,100)$

Constipation $(6,100)$

Diarrhea $(3,100)$

General well-being $(1,33.3)$, menorrheal pain $(1,33.3)$, colic in GIT $(1,33.3)$

Common cold $(6,66.7)$, anxiety $(3,33.3)$

Colic in GIT $(1,100)$

For healing of wounds (1, 100)

Cough $(1,100)$

Condiment $(1,50)$, dizziness $(1,50)$

Condiment $(1,50)$, colon colic $(1,50)$

Decreasing hair growth $(1,100)$

Colic in GIT $(2,100)$

For general well-being $(4,100)$

margarine, and then water is added with continuous stirring. Taken with

Moistened powder in a gauze, then

Decoction or infusion

Decoction, entire fruits, powder
Peptic ulcer $(3,42.9)$, anti-inflammatory $(4,57.1)$

Renal colic $(2,66.7)$, colon problems $(1,33.3)$

Hypertension (36, 97.3), antimicrobial $(1,2.7)$

Hypertension (2, 50), dyspepsia $(1,25)$, cardiotonic $(1,25)$

Antiseptic for skin $(2,100)$

Insomnia $(1,25)$, colon colic $(1,25)$, cough $(1,25)$, antiseptic for skin $(1,25)$ 
Table 2 Medicinal plant species, plant parts used and ailments treated by local people of Beni-Sueif, Egypt (Continued)

\begin{tabular}{|c|c|c|}
\hline $\begin{array}{l}\text { Mentha piperita L. (Lamiaceae), Na'na, cultivated, } \\
\text { CAIM125, L }\end{array}$ & Decoction & Colic in GIT $(28,87.5)$, anxiety $(4,12.5)$ \\
\hline $\begin{array}{l}\text { Myristica fragrans Houtt. (Myristicaceae), Gawz et tib, } \\
\text { imported, CAIM132, S }\end{array}$ & Powder & Condiment $(1,100)$ \\
\hline $\begin{array}{l}\text { Nigella sativa L. (Ranunculaceae), Habbet el barakah, } \\
\text { cultivated, CAIM139, S }\end{array}$ & Powder, entire seeds & Immuno-stimulant $(2,50)$, condiment $(2,50)$ \\
\hline $\begin{array}{l}\text { Orchis hircine Crantz. (Orchidaceae), Sahhlab, } \\
\text { imported, CAIM133, Rt }\end{array}$ & $\begin{array}{l}\text { Powdered rots are boiled in milk } \\
\text { with continuous stirring }\end{array}$ & Peptic ulcer $(1,100)$ \\
\hline $\begin{array}{l}\text { Origanum majorana L. (Lamiaceae), Bardaqush, } \\
\text { cultivated, CAIM126, L }\end{array}$ & Decoction & $\begin{array}{l}\text { Stomach troubles and coli }(1,50) \text {, hypertension } \\
(1,50)\end{array}$ \\
\hline $\begin{array}{l}\text { Petroselinum sativum Hoffm. (Apiaceae), Baqdunis, } \\
\text { cultivated, CAIM143, L }\end{array}$ & Green leaves in salad & Urinary tract infection $(2,100)$ \\
\hline $\begin{array}{l}\text { Pimpinella anisum L. (Apiaceae), Anisun, cultivated, } \\
\text { CAIM108, Fr }\end{array}$ & Decoction, infusion & $\begin{array}{l}\text { Renal colic }(2,5.9) \text {, colic in GIT }(11,32.4) \text {, upper } \\
\text { respiratory tract problems }(19,55.9) \text {, anxiety } \\
(2,5.9)\end{array}$ \\
\hline $\begin{array}{l}\text { Piper nigrum L. (Piperaceae), Fulful aswad, cultivated, } \\
\text { CAIM146, Fr }\end{array}$ & Powder & Condiment $(1,100)$ \\
\hline $\begin{array}{l}\text { Plantago afra L. (Plantaginaceae), Bazr qatuna, } \\
\text { cultivated, CAIM135, S }\end{array}$ & Powder & Antiseptic for skin $(1,100)$ \\
\hline $\begin{array}{l}\text { Portulaca oleracea L. (Portulacaceae), Riglah, wild, } \\
\text { CAIM136, L, S }\end{array}$ & $\begin{array}{l}\text { Painful joints are exposed to steam } \\
\text { evaporating from boiling leaves with } \\
\text { water, powdered seeds }\end{array}$ & $\begin{array}{l}\text { Rheumatic pain }(2,50) \text {, stomachic appetizer }(2, \\
50)\end{array}$ \\
\hline $\begin{array}{l}\text { Psidium guajava L. (Myrtaceae), Guwafah, cultivated, } \\
\text { CAIM147, L }\end{array}$ & Decoction & Cough and cold $(3,100)$ \\
\hline $\begin{array}{l}\text { Rosmarinus officinalis L. (Lamiaceae), Hassa el-ban, } \\
\text { cultivated, CAIM127, L }\end{array}$ & Infusion, volatile oil & $\begin{array}{l}\text { Carminative }(1,33.3) \text {, diuretic }(1,33.3) \text {, antiseptic } \\
(1,33.3)\end{array}$ \\
\hline $\begin{array}{l}\text { Salvia officinalis L. (Lamiaceae), Maryamiyah, } \\
\text { cultivated, CAIM128, L }\end{array}$ & Infusion & $\begin{array}{l}\text { Colic in GIT }(3,60) \text {, antiseptic }(1,20) \text {, common } \\
\text { cold }(1,20)\end{array}$ \\
\hline $\begin{array}{l}\text { Solenostemma argel Hayne (Asclepiadaceae), Hhargal, } \\
\text { wild, CAIM109, L }\end{array}$ & Infusion & Antispasmodic for renal colic $(2,100)$ \\
\hline $\begin{array}{l}\text { Tamarindus indica L. (Caesalpiniaceae), Tamer Hindi, } \\
\text { imported, CAIM117, Fr }\end{array}$ & Decoction & Laxative $(3,100)$ \\
\hline $\begin{array}{l}\text { Thymus vulgaris L. (Lamiaceae), Za'tar, cultivated, } \\
\text { CAIM129, L }\end{array}$ & Powder & Condiment $(4,100)$ \\
\hline $\begin{array}{l}\text { Tilia sylvestris Desf. (Tiliaceae), Zayzafun, imported, } \\
\text { CAIM148, L, F }\end{array}$ & Decoction & Cough due to common cold $(2,100)$ \\
\hline $\begin{array}{l}\text { Trigonella foenum-graecum L. (Fabaceae), Hhelbah, } \\
\text { cultivated, CAIM122, S }\end{array}$ & Decoction & $\begin{array}{l}\text { Diuretic }(1,4) \text {, colic in GIT }(14,56) \text {, nutritive }(9, \\
36) \text {, diabetes }(1,4)\end{array}$ \\
\hline $\begin{array}{l}\text { Zingiber officinale Roscoe (Zingiberaceae), Zangabil, } \\
\text { imported, CAIM145, R }\end{array}$ & Decoction & Voice problems in common cold $(4,100)$ \\
\hline
\end{tabular}

These plants are cultivated plants and widely used in the Egyptian folk medicine [13]. There are a lot of studies about the pharmacological activities of these plants; Hibiscus sabdariffa [14-18], Mentha piperita [19], Trigonella foenum-graecum [20,21] and Pimpinella anisum [22,23]. We have decided to present here the most significant and important studies related to the uses mentioned in our study. The uncommon ethnopharmacological uses of Glossostemon bruguieri Desf., Lupinus albus, Orchis hircine and Portulaca oleracea L. deserves phytochemical and pharmacological studies to examine the reported activities. Some of the uses mentioned are in agreement with those previously reported in the Mediterranean region [24]. For example, Portulaca oleracea was reported to be used in muscular-skeletal diseases and for nutritional purposes in Albania, Ammi visnaga for kidney and respiratory diseases in Algeria and Egypt, Coriandrum sativum as digestive in Algeria, Foeniculum vulgare as digestive in Algeria and Cyperus, Solenostemma argel for kidney diseases in Egypt, Mentha piperita for mental-nervous disorders in Algeria, Hibiscus sabdariffa for cardiovascular disorders in Egypt.

\section{Conclusions}

The current study targeted the medicinal plants used by local people of Beni-Sueif, Upper Egypt. Beni-Sueif is a biodiversity area rich of wide-variety of plant species. The calculated $F_{I C}$ and FI values were used as a tool to understand which illnesses are preferentially treated with medicinal plants. Gastrointestinal problems, cough 
and hypertension were the main illnesses treated by medicinal plants in Beni-Sueif governorate. People may use medicinal plants as an adjuvant therapy to treat these illnesses due to the common occurrence of the former two illnesses and the chronic nature of the latter illness. This may be the reason for why these illnesses have high agreement values. The preservation of the traditional knowledge is an essential requirement for maintaining traditional Egyptian medicine as a cultural resource.

\section{Acknowledgements}

This research work was supported by a research grant from the International Foundation for Sciences (Project No. AF/19300).

\section{Author details}

${ }^{1}$ Department of Pharmacognosy, Faculty of Pharmacy, Beni-Sueif University, P.O. Box 62111, Beni-Sueif, Egypt. ${ }^{2}$ Department of Flora \& Phyto-Taxonomy Researches, Horticultural Research Institute, Agricultural Research Centre, P.O. Box 12311, Giza, Egypt.

\section{Authors' contributions}

SA carried out the fieldwork, analysis of the data and drafting the manuscript. AM authenticated the plant samples. All authors read and approved the final manuscript.

\section{Competing interests}

The authors declare that they have no competing interests.

Received: 20 October 2009 Accepted: 27 June 2011

Published: 27 June 2011

\section{References}

1. Kamal H: A Dictionary of Pharaonic Medicine. Cairo: The National Publication House; 1967.

2. Manniche L: An Ancient Egyptian Herbal. Texas: University of Texas Press: 1999.

3. The Information and Decision Support Center. [http://www.idsc.gov.eg].

4. Boulos L: Flora of Egypt. Cairo: Al Hadara Publishing Inc; 1991.

5. Martin GJ: Ethnobotany: A Method Manual. London: Chapman and Hall; 1995.

6. Bedevian AK: Illustrated Polyglottic Dictionary of Plant Names. Cairo: Madbouli bookshop; 1994.

7. Heinrich M, Ankli A, Frei B, Weimann C, Sticher O: Medicinal plants in Mexico: healer's consensus and cultural importance. Soc Sci Med 1998, 47:1859-1871.

8. Friedman J, Yaniv Z, Dafni A, Palewitch D: A preliminary classification of the healing potential of medicinal plants, based on a rational analysis of an ethnopharmacological field survey among Bedouins in the Negev desert, Israel. J Ethnopharmacol 1986, 16:275-287.

9. Alcorn JB: Factors influencing botanical resource perception among the Huastec: Suggestions for future ethnobotanical inquiry. J Ethnobiol 1981, 1:221-230.

10. Alcorn JB: Development policy, forest and present farms: Reflections on Huastec managed forest's contribution to commercial production and resource conservation. Econ Bot 1984, 38:389-406.

11. Dobriyal RM, Singh GS, Rao KS, Saxena KG: Medicinal plant resources in Chhakinal Watershed in the north western Himalaya: Traditional knowledge, economy and conservation. J Herbs Spices Med Plants 1997, 5:15-27.

12. Botha J, Withowski ETF, Shackleton CM: Market profiles and trade in medicinal plants in the Lowveld, South Africa. Environ Conserv 2004, 31:38-46.

13. Hammoda F: Medicinal Plants and Herbs. Cairo: Al-ahram centre for translation and publication; 1993.
14. Kim JK, So H, Youn MJ, Kim HJ, Kim Y, Park C, Se-Jin Kim SJ, Ha YA, Chai KY, Kim SM, Kim KY, Park R: Antihypertensive effect of an aqueous extract of the calyx of Hibiscus sabdariffa. Fitoterapia 2007, 78:292-297.

15. Ajay M, Chai HJ, Mustafa AM, Gilani AH, Mustafa MR: Mechanisms of the anti-hypertensive effect of Hibiscus sabdariffa L. calyces. J Ethnopharmacol 2007, 109:388-393.

16. Herrera-Arellano A, Flores-Romero S, Chávez-Soto MA, Tortoriello J: Effectiveness and tolerability of a standardized extract from Hibiscus sabdariffa in patients with mild to moderate hypertension: a controlled and randomized clinical trial. Phytomed 2004, 11:375-382.

17. Odigie IP, Ettarh RR, Adigun SA: Chronic administration of aqueous extract of Hibiscus sabdariffa attenuates hypertension and reverses cardiac hypertrophy in 2K-1C hypertensive rats. J Ethnopharmacol 2003, 86:181-185.

18. Faraji MH, Tarkhani AHH: The effect of sour tea (Hibiscus sabdariffa) on essential hypertension. J Ethnopharmacol 1999, 65:231-236.

19. Grigoleit HG, Grigoleit P: Gastrointestinal clinical pharmacology of peppermint oil. Phytomed 2005, 12:607-611.

20. Eidi A, Eidi M, Sokhteh M: Effect of fenugreek (Trigonella foenum-graecum L) seeds on serum parameters in normal and streptozotocin-induced diabetic rats. Nutrit Res 2007, 27:728-733.

21. Amin A, Alkaabi A, Al-Falasi S, Daoud SA: Chemopreventive activities of Trigonella foenum graecum (Fenugreek) against breast cancer. Cell Biol Int 2005, 29:687-694.

22. Tirapelli CR, de Andrade CR, Cassano AO, De Souza FA, Ambrosio SR, da Costa FB, de Oliveira AM: Antispasmodic and relaxant effects of the hidroalcoholic extract of Pimpinella anisum (Apiaceae) on rat anococcygeus smooth muscle. J Ethnopharmacol 2007, 110:23-29.

23. Lee R, Balick MJ: Flu for you? The common cold, influenza, and traditional medicine. EXPLORE: The Journal of Science and Healing 2006, 2:3252-3255

24. Gonz'alez-Tejero MR, Casares-Porcel M, S'anchez-Rojas CP, RamiroGuti'errez JM, Molero-Mesa J, Pieroni A, Giusti ME, Censorii E, de Pasquale C, Della A, Paraskeva-Hadijchambi D, Hadjichambis A, Houmani M, ElDemerdash M, El-Zayat M, Hmamouchi M, ElJohrig S: Medicinal plants in the Mediterranean area: synthesis of the results of the project Rubia. J Ethnopharmacol 2008, 116:341-357.

doi:10.1186/1746-4269-7-18

Cite this article as: AbouZid and Mohamed: Survey on medicinal plants and spices used in Beni-Sueif, Upper Egypt. Journal of Ethnobiology and Ethnomedicine 2011 7:18.

\section{Submit your next manuscript to BioMed Central and take full advantage of:}

- Convenient online submission

- Thorough peer review

- No space constraints or color figure charges

- Immediate publication on acceptance

- Inclusion in PubMed, CAS, Scopus and Google Scholar

- Research which is freely available for redistribution 